Tér és Társadalom 17. évf. 2003/4. 157-171. p.

Tér és Társadalom

XVII. évf. 2003

4: $157-171$

\title{
TÉRTÖRTÉNET
}

\section{AZ OSZTRÁK-MAGYAR HATÁR KIJELÖLÉSE UTÁNI PROBLÉMÁK RENDEZÉSE}

\author{
(Problem Settlement after the Determination \\ of the Austrian-Hungarian Border)
}

\section{SALLAI JÁNOS}

Kulcsszavak:

Államhatár nemzetközi megállapodások osztrák-magyarhatár

Az osztrák-magyar államhatár egy korábban egységes teriuletet vágott szét, nagymértékben akadályozva a határ mentén élōk mindennapi életét. Cikkünk e határ születésének gyakorlati körülményeit mutatja be, majd azokat a múlt század húszas éveiben keletkezett nemzetközi megállapodásokat, amelyek a határ menti lakosság és gazdaság korábban megszokott életvitelének, kapcsolatainak fenntartását szolgálták. Ezeket a napjainkban is tanulságos megállapodásokat a szerző mintegy forráselemzésként közli, mellékelve egy másik korban, az ötvenes években született felülbírálat jegyzökönyveit is.

\section{Bevezetö}

A monarchia széthullását követöen Magyarország egy teljesen új földrajzi környezetben, új államhatárok mentén megszületett ,nemzetállamok” szomszédságában kezdte meg a 20. század harmadik évtizedében az önálló életét. A szomszédok közül Magyarországot sajátos történelmi hagyományok kötötték Ausztriához, amely szintén el-vesztette birodalmi jellegét, és próbált alkalmazkodni a megváltozott körülményekhez.

Az új körülmények minden irányba új kapcsolatok kialakítását eredményezték a kitủzött határok mentén. A tanulmány első részében osztrák-magyar viszonylatban bemutatjuk a határok kitüzésének folyamatát, majd a második fö részben a határrendhez kapcsolódó nemzetközi szerződéseket és a kishatárforgalmat. A két ország kapcsolatát jelentősen befolyásolta a második világháborút követő nemzetközi erőviszonyok alakulása, ami vasfüggöny felépítéséhez, és a korábbi nemzetközi megállapodások elhalásához vezetett. Erre figyeltek fel a Határőrség szakemberei 1954-ben, amikor felülvizsgálták az osztrák-magyar jogi szerződéseket, és konstatálták a teendőket.

A jegyzökönyvek elözményei az osztrák-magyar államhatár trianoni (velencei) döntést követö kijelöléséhez datálhatók. A magyar-osztrák határ megállapítása a több évszázados kötödés ellenére több nehézségbe ütközött. Ausztria részéről Nyugat-Magyarország megtartási szándéka politikai konfliktushoz vezetett. A végleges 
kỏzös államhatár kijelöléséig ezért igen hosszú és bonyolult út vezetett (Sallai 1996; 2002; Suba 1999).

1918 őszén a dualista állam részeire bomlásával párhuzamosan megkezdődött a békeszerződés kidolgozása. A korábbi közös múlt ellenére a politikai életben meglepetésként hatott Renner kancellár kijelentése, amikor megfogalmazta Ausztria igényeit Nyugat-Magyarország területére. Ezzel párhuzamosan a szomszédos szláv államok titkos tárgyalásokat folytattak, hazánk területének terhére, egy korridor létrehozására. A Párizsban folyó békekonferencia elismerte az osztrák területi igényt, amely új helyzetet teremtett a térségben, és fegyveres konfliktusokhoz, atrocitásokhoz vezetett. A tỏrténelmi Magyarország teriletén, Németújváron, 1919. augusztus 17-én tartott népgyúlésen résztvevők a Magyarországtól való elszakadást hangoztatták.

A békefolyamat fontos állomása volt 1919. szeptember 10., amikor Saint Germain-ben Ausztria képviselői aláírták a békeszerzódést. Magyarország ekkor még csak készült, hogy Párizsba küldje a magyar érdekeket képviselő kủldöttségét, amelynek vezetője gróf Apponyi Albert lett.

A magyar béketárgyalások sorsát dỏntỏen befolyásolta a Millereand levél, amely a következő lényeges megfogalmazásokat tartalmazta: „... A szövetséges és társult hatalmak hivek ahhoz a szellemhez, mely óket a béke által megállapitott határok kijelölésénél eltöltötte, foglalkoztak azzal a lehetöséggel is, hogy az igy kijelölt határ esetleg nem felel meg mindenütt pontosan a néprajzi vagy gazdasági követelményeknek. Lehetséges, hogy egy helyszini vizsgálat bebizonyítja majd a békeszerzödésben vett határok egyes pontokon való megváltoztatásának szükségességét... Ebben az esetben a szövetséges és társult hatalmak hozzájárulnak ahhoz, hogy a szövetség tanácsa, ha a tekintetbe jövö felek egyike azt kivánta, felajánlhassa jó szolgálatait az eredeti határok békés úton való kiigazitására, ugyanazon feltételek mellett, azokon a helyeken, ahol egy határbizottság valamely változtatást kivánatosnak tartott..."

A fentiek azt sugallták a magyar fél számára, hogy az elfogadhatatlannak tủnő trianoni határok módosítására sor keruilhet a helyszíni határ megállapítások során. Ennek hatására a magyar küldöttséget felhatalmazták a békeszerezódés aláirására, amelyre 1920. július 4-én, Trianonban került sor. A szerződés aláírását kővetően a Nagykỏvetek Tanácsa által kiadott „Általános Utasítások” értelmében megszervezỏdik az osztrák-magyar határmegállapító bizottság. A politikai tárgyalások mellett a határterületen nyugtalansåg uralkodott el. 1920. augusztus 8-án sor került a Szentgotthárdi akcióra. Ennek keretén belúl magyarok osztrảk területre hatoltak be, fegyverszerzés céljából. A politikai helyzetet tovább bonyolította, hogy késỏbb magyar területen IV. Károly király személyesen is megjelent.

A két ország kỏzött folyó tárgyalảsok eredményekẻnt 1921. augusztus 3-án Bécsben, Schober kancellár és Pogatscher osztályfőnök, valamint magyar részröl Masirevich nagykövet és Gratz volt külügyminiszter megállapodtak, melynek értelmében Nyugat-Magyarország egyharmada Magyarországé marad. Az osztrák külügyi bizottság azonban ezt elutasította, igy nem léphetett érvénybe. 
A későbbi időszakban ismét elötérbe kerülnek a fegyveres akciók. 1921. augusztus 15-én, az 1. (Prónay) csendőr-tartalék zászlóalj Felsőőrre, a 2. (Ostenburg) csendör-tartalék zászlóalj Kismartonba vonult be, majd megkezdődött a kezdetben sikeres, később tiszavirág életủ küzdelem az osztrák csendőrökkel.

A közben folyó határmegállapító tárgyalások fontos mozzanatára került sor 1921. szeptember 24-én, amikor az osztrák-magyar határmegállapító bizottság plenáris ülést tartott, és a következő határozatot hozta: ,hogy a két érdekelt delegáció a határkiigazításra vonatkozólag javaslatokat nyújtson be, és felosztotta az egész határvonalat három szakaszra, amelyek közül az elsö (,A” szakasz) a köpcsényi (Kittsee) hármasponttól Moson vármegyének a Fertö-tóban levö hármas (IllmiczFertörákos-Kroisbach és Fertömeggyes-Mörbisch) találkozási pontjáig terjed, a második (,B” szakasz) pedig innen az Irottköig, és a harmadik („C" szakasz) a tókai hármaspontig. Ez a három szakaszra való beosztás nagyjában alkalmazkodik a három vármegye közigazgatási határaihoz, amennyiben az elsö szakasz teljesen Moson vármegye területére esik, és csak a második szakasz vesz a Sopron vármegyébe esö területhez még a Vas vármegyei területröl egy kb. $10 \mathrm{~km}$ hosszúságú vonalat, úgy, hogy a harmadik szakasz ezen kis rész kivételével ismét az egész Vasvármegyébe esö részt foglalja magába".

A kialakult zavaros helyzet megszüntetése céljából az olaszok közvetítő szerepre vállalkoztak a volt dualista állam két tagja között, ennek eredményeként megszületett a Velencei jegyzökönyv, 1921. november 11-13-án. Az osztrák kormány hozzájárulását adta, hogy Sopronban és környékén népszavazást tartsanak. A magyar kormány vállalta, hogy Nyugat-Magyarországról eltávolítja a felkelőket. Ez egyben Prónayék uralmának végét jelentette. A magyar sikert hozó soproni népszavazásra nemzetközi erök felügyeltek.

Ugyanebben az idöszakban, még 1921 decemberében döntöttek a magyar határmegállapító delegáció összetételéről.

A népszavazást követően sor kerülhetett a határok kitüzésére, amely folyamat állandóan nehézségekbe ütközött. Ennek egyik legszemléletesebb megnyilvánulása, hogy több település hovatartozása 1921-22-ben dölt el. A határmegállapítás eredményeként a Népszövetségek Tanácsának döntése következtében visszatért Magyarországhoz Kis- és Nagynarda, Alsó- és Felsöcsatár, Német- és Magyarkeresztes, Horvátlövő, Pornóapáti. A Magyarországnak ítélt Rendeket és Rőtfalvát osztrák kezdeményezésre elcserélték Ólmód és Szentpéterfa községekre.

A határmegállapítás eredményeként az osztrák-magyar határ hossza: $375 \mathrm{~km} 517 \mathrm{~m}$. Szakaszok szerint: C szakasz - 140 km 544 m; B szakasz - 126 km 366 m; A szakasz - $108 \mathrm{~km} 607 \mathrm{~m}$.

A határ kitűzésére az osztrákok részéről természetes, a magyarok részéről műkövet használtak fel, a jeleket átlagosan $100 \mathrm{~m}$ távolságra helyezték el egymástól.

A határszerződésben leírtak szerint: „Az új állami határvonal a Magyar Királyság és az Osztrák Köztársaság között három szakaszra osztatott, mely szakaszok A, B, $\mathrm{C}$ betükkel jelöltettek meg. Az A szakasz a Köpcsény-Kittsee hármas országhatár- 
ponttól (Magyarország, Ausztria és Csehszlovákia közös határpontja) a Fertö tóban elhelyezett szakaszhatárkőig, a B szakasz a megnevezett szakaszhatárkőtöl az Irottkőig (883. magassági pont), a C szakasz az Irottkötöl a tókai hármas országhatårpontig (Tauka, 380. magassági pont; Ausztria, Magyarország és a Szerb-HorvátSzlovén Állam közös határpontja) terjed.

Minden szakasz hat alszakaszra osztatott, melyek szakaszonként északtól kezdődóleg római számjegyekkel jelöltettek meg. (A I.; A II., stb., B I., B II., stb.). Ezen beosztás azonban a határkövek számozásánál feltüntetést nem nyert, mert csak a műszaki munkák célszerübb megszervezése, $\mathrm{s}$ a végsố okmányok áttekinthetőbb csoportosítása érdekében történt.

A kitüzơtt új határok soha nem tapasztalt nehézségek elé állították a magyar állam vezetöit és a magyarságot. Az a tény, hogy az új határoknak (a korábbival ellentétben) jelentős része mesterséges jellegüvé vált, és a határ túloldalán a határvonallal párhuzamosan magyar nemzetiségú területsáv keletkezett, egy sor államigazgatási, kapcsolattartási problémát vetett fel. Az így kialakult helyzet során rokoni, közigazgatási, gazdasági, infrastrukturális és még sorolhatnánk, hogy milyen kapcsolatok szakadtak szét. Az újonnan kitủzött határ mentén a Vámőrség látta el a határörizetet (és a kishatárforgalom ellenörzését). A távolsági forgalom ellenőrzését az Állami Rendőrségbe beolvasztott Határrendőrség kapitányságai végezték. A kialakult helyzetre az akkori politikai vezetés a kishatárforgalom intézményének létrehozását látta megoldásként, mellyel biztosította a határ menti magyar települések közti érintkezés fenntartását. Ezért minden szomszédos országgal tárgyalást kezdeményezett a témában, és ezek eredményeként az 1920-as évek második felében a tárgyalások megállapodással zárultak.

A kishatárforgalom szabályozását, elsöként általánosan az 5.300/1923 M.E. rendelet jelenítette meg. E rendeletben rögzítették, hogy a kishatárforgalom területi hatálya a határkerületre terjedt ki, mely alatt a vámhatárral párhuzamos $10-15 \mathrm{~km}$ es terület sávot kellett érteni. A pontos területi hatályt minden viszonylatban a szerzỏdés mellékleteként az érintett községek, települések felsorolásával tüntették fel.

A kishatárforgalomban részt vevỏ lakosok a határt útlevéllel, határszéli igazolvánnyal, birtokos úti igazolvánnyal és alkalmi úti lappal léphették át. A határátlépés helyét (mely nemcsak a határátkelö, hanem megegyezés szerint vámút is lehetett) a két szomszédos ország által megkötött szerződésben határozták meg. A kettös birtokosok, valamint azok részére, akik munkavégzés vagy foglalkozásuk folytán naponta többször átlépték a határt, határszéli igazolványt állítottak ki. Az igazolvány kiállításának körülményeit, formáját, tartalmát, annak érvényességi időtartamát a fenti rendelet pontosan szabályozta. Továbbá a rendeletet követték a szomszédos államokkal kötött kishatárforgalmi szerződések, melyek az adott viszonylatban a sajátosságokat, a pontos területi hatályosságot rögzítették.

A kisebb határszéli személyforgalom szabályozása tárgyában a 11.110/1926 M.E. számú kormányrendeletben' gondoskodtak az Osztrák Köztársasággal kötött megállapodás életbeléptetéséröl. 
Ennek értelmében az osztrák-magyar kishatárforgalom fóbb sajátosságai:

- A határkerületet $15 \mathrm{~km}$ mélységủ területsávban jelölte meg.

- Határszéli úti igazolvány járt a határkerületi lakosok és a földbirtokosok (bérlök) részére.

- Ez az okmány 8 napi tartózkodást tett lehetővé a másik országban.

- A határátlépést biztosító alkalmi úti lap egyszeri, menet-jövet átlépést és legfeljebb 3 napi tartózkodást engedélyezett. Föleg a sürgös családi problémák rendezését és turisztikai célokat szolgált.

- A határt napkeltétől, napnyugtáig lehetett átlépni.

- Az osztrák és a magyar átellenes határterületek helységneveinek pontosítása, helyesbítése Magyarországon az 129.013/1927 P.Ü.M. rendeletben került kihirdetésre.

- A vám- és mellékutak jegyzékét a 111.070/P.Ü.M. rendelet tette közhírré. A fenti rendeletben nem rögzített úton vagy egyéb ponton a határvonalat áruval, áru nélkül tilos volt átlépni. Kivételt azok a birtoktulajdonosok élveztek, akik mezsgyehatáron belül a határvonalat bárhol átléphették.

A kishatárforgalom a második világháború után egy rövid ideig, 1948-ig létezett, majd osztrák viszonylatban a szerzödés felmondását követöen teljesen elhalt. A határ menti életet megkönnyítö határátlépési lehetőségek helyébe a „vasfüggöny”, majd az elektromos jelzörendszer lépett. A kishatárforgalom jelentóségét erösíti az a tény, hogy a jogi jegyzőkönyvekben szereplő megállapodások esetében is több alkalommal megemlítésre került.

A kapcsolattartás mellett az a tény, hogy az új osztrák-magyar államhatár korábbi közigazgatási, etnikai és birtokhatárokat, közmủveket vágott ketté, egy sor rendezésre váró problémát okozott. Az elözö részben bemutatott, magyar- osztrák határvonal kijelölése során felmerült jogi kérdések rendezése céljából a Határmegállapító Bizottság jogi jegyzökönyveket készített. Ezeket a jegyzökönyveket a két kormány képviselöi - az általuk kiegészítésképpen készített jogi jegyzökönyvekkel együtt - egyezmény formájában rögzítették le.

A szóban forgó, összesen 22 db jogi jegyzökönyvet magában foglaló Egyezményt Bécsben, 1927. március hó 11. napján írták alá. Az egyezmény, a határvidék vízügyi kérdéseit rendezö jogi jegyzökönyvek kivételével, a megerösítő okmányok kicserélésének napján, 1928. március 26-án lépett életbe. A határvidék vízügyeit rendezö jogi jegyzőkönyveket, az Osztrák-Magyar Határmegállapító Bizottság 1924. július 9-én hozott döntése alapján, 1923. január 1-töl érvényben lévöknek kellett tekinteni.

A jogi jegyzőkönyveket magában foglaló egyezményt a magyar kormány 1928. április 28-án, az 1970/1928. M. E. sz. rendelettel tette közzée. A jogi jegyzőkönyvekkel kapcsolatosan felmerül az érvényesség kérdése. Az 1943. október 30-i moszkvai háromhatalmi nyilatkozat Ausztriának, a hitleri Németország által történt bekebelezését semmisnek nyilvánította. Ennek alapján az Osztrák Köztársaság által, 1938. március 13-a elött kötött minden nemzetközi egyezményt a II. világháború után is érvényben levőnek kellett elismerni, amennyiben felmondásukra intézkedés nem történt. 


\section{Az 1927-ben született jogi jegyzókönyvek bemutatása, és az 1954. évi magyar belügyi felülvizsgálat ${ }^{3}$ véleménye}

Jelen fejezetben bemutatjuk a két ország által kötött jegyzökönyveket, melyeknek születési körülményeit a fentiekben ismertettük, s mellette idézzük az 1954-ben végzett magyar belügyi felülvizsgálat által megállapítottakat, amelyek ezen jegyzökönyvek további sorsát meghatározták.

A határvidék vízügyi viszonyaira vonatkozó ${ }^{4}$ jogi jegyzökönyvben a magyar és osztrák kormányok kötelezik magukat arra, hogy egyoldalúan semmi olyan intézkedést nem tesznek, amely a magyar-osztrák határvidék vízügyi viszonyait érintené. Nem végeznek továbbá egyoldalúan semmi olyan munkálatot, amely a másik állam területén a meglévő vízügyi viszonyokban változást idézne elö. Kötelezik magukat az államok a vízi mủvek jó karban való fenntartására.

Külön kiemeli a jegyzőkönyv, hogy az árvízvédelem érdekében mindkét állam részére kötelező a szomszéd állam veszélyeztetett területének védelmét szolgáló múszaki berendezések jó állapotban tartása.

A jegyzőkönyv második részében a Rába-Szabályozó Társulatra vonatkozó rendelkezéseket tárgyalja.

Elöŕrja a jegyzőkönyv, hogy a Hanság Csatorna, valamint a hozzá tartozó vízi mủvek állapotán úgy méretek, mint vízhozam tekintetében bármiféle változtatást csakis elözetes megegyezés alapján lehet foganatosítani.

Tartalmaz még a jegyzőkönyv a volt Rába-Szabályozó Társulat felosztásával kapcsolatos pénzügyi rendelkezéseket is.

Az 1954-es jegyzőkönyv megállapításai szerint: „Ez a jegyzőkönyv olyan kötelezettségeket ró Ausztriára, melyek számunkra feltétlenül elönyösek. A magyar területek ugyanis általában mélyebben fekszenek, mint az osztrák vidékek, tehát árvízvédelmi szempontból fontos az, hogy a vízügyi kérdések rendezettek legyenek. Az árvízvédelmi szabályok betartása feltétlenül kihatással van a határörizetre is. Az osztrák határon ugyanis mintegy 12 helyen van vízi határ, és több más helyen pedig patakok, vagy vílevezetö árok keresztezik a határvonalat. A tavaszi áradások alkalmával esetleg bekövetkezö árvizek igen erösen gyöngítenék a határörizetet."

A határ megvonása után a brennbergi szénbányák müvelési területének egy része osztrák területre került. Ezért született meg a brennbergi bányák müvelésére vonatkozó jogi jegyzókönyv. Ebben Ausztria elismeri, hogy a Borbála és Ilona akna mủvelése a továbbiakban is gazdasági egységet alkot. Az osztrák területnek azon a részén, amelyre a mủvelés jelenleg vagy a jövőben kiterjed, továbbra is a magyar bányaigazgatóság kezelése alatt marád a bánya.

A bányászok és bányaalkalmazottak a bányászok védelmét szolgáló magyar törvényeknek vannak alávetve, még akkor is, ha osztrák területen dolgoznak.

Ausztria engedélyezi a bányamủveléshez szükséges anyagok (fóleg fa) adómentes kivitelét. Ausztria Magyarország javára felfüggeszti 1963-ig a szénkutatást és szén- 
kitermelést, a Brennbergbányához közel eső három község - Ritzing, Lackendorf és Latzenbach területén.

A szerződés II. cikkelye szerint: „Ausztria a bányabiztonsági rendörsége erösitése érdekében kötelezi magát, hogy Récény (Ritzing) községnek a vázrajzon vörös színnel jelölt 65. számú katasztrális parcella csoport területén osztrák csendörörsöt állit fel és tart fenn."

A jegyzőkönyv kizárólag Magyarország számára biztosít jogosítványokat a brennbergi bányamüveléssel és szénkutatással kapcsolatban. Az erre illetékes hatóságok a brennbergi bányamüvelést beszüntették, tehát jelenleg a jegyzőkönyvben számunkra biztosított jogosítványokkal nem élünk. A bánya mủvelése határörizeti szempontból komoly nehézségeket jelentene, ugyanis egyrészt a bánya nagy része osztrák terület alatt fekszik, másrészt pedig munkavállalóinak nagy része osztrák lakosokból tevődött össze.

Az 1954-es jegyzőkönyv idevágó megállapításai: „1938-ban kb. 160 fö járt át Ausztriából a magyar bányába dolgozni. Jelenleg az egész bánya le van szerelve, az aknák vízzel vannak elárasztva. Nem valószínü tehát, hogy a népgazdaság igényt tartana a jövóben az ottani bányászatra. Ilyen formán nyilatkozott a Nehézipari Miniszter kiküldötte is. A brennbergi bányával foglalkozó jogi jegyzökönyv tehát már egyáltalán nem idöszerü és a jegyzökönyv felmondása határörizeti szempontból elönyös és indokolt."

A Pinka-völgyi forgalom szabályozása tárgyában lefektetett jogi jegyzökönyv értelmében azok a személyek, akiknek a jegyzőkönyvben feltuntetett, mintegy 34 községben állandó lakása van, a határ menti átmeneti forgalomban könnyítésekben, illetve előnyökben részesültek. Az átmeneti területeken az úti okmányban feltüntetett cikkek átmenő forgalma és szállítása vám- és illetékmentesen történhetett.

A jegyzökönyv szerint a következö községek területén valósulhatott meg az átmeneti forgalom:

„Németbükkös, Németlövö, Monyorókerék, Abdalóc, Pinkakertes, Karácsfa, Szentkút, Pokolfalu, Kólom, Lovászad, Nagysároslak, Felsöbled, Rohonc, Csajta, Csém, Csejke, Pósaszentkatalin, Strém, Alsóbeled, Pinkatótfalu, Alsócsatar, Bozsok, Bucsu, Felsöcsatár, Horvátlövö, Kisnarda, Magyarkeresztes, Nagykölked, Nagynarda, Németkeresztes, Pinkamindszent, Pornóapáti, Szentpéterfa, Vasalja." A jegyzőkönyv mellékleteként kiadott útirány táblázat pontosan rögzítette, hogy „mely községekböl, mely községeken át, mely községekbe” lehet menni. Mivel a jegyzökönyv 1922-ben készült, ezért a határkijelölés és település-cserék révén beállt végleges változatot még nem tudta figyelembe venni. Így történhetett meg, hogy Szentpéterfa mint osztrák település szerepel.

A jegyzőkönyv jogot és kötelességet állapít meg mindkét állam részére. Az államok türni kötelesek, hogy a szomszéd állam erre jogosult lakói az ő területén keresztül járjanak. 
A jogi jegyzőkönyv VIII. cikke elöírja, hogy „minden egyes átmenő lakosnak a kishatárszéli forgalomra vonatkozó egyezményn $\mathrm{k}^{5}$ megfelelően kiállított, érvényes határátlépési igazolvánnyal kell rendelkeznie".

Az 1954-es jegyzőkönyvben a következőket jegyezték meg: „A szóban forgó kishatárszéli forgalmi egyezményt, melyet a két állam 1926-ban kötött, a bécsi magyar követség útján Magyarország 1948. december 1-jével felmondta. - Ekkor megszünt osztrák viszonylatban minden helyi jellegü határforgalom. A fentiek alapján a jogi jegyzőkönyv érvényben tartása tehát teljesen felesleges. Határörizeti érdekeink alapján a jegyzőkönyvben foglalt jogi kötöttségünket feltétlenül meg kell szüntetni."

$\mathrm{Az}$ 1. számú jogi jegyzókönyv, Sopron városának Lépesfalva (Loiperbach) osztrák község területén való átvitelt igénylö erdötermékei szállitására vonatkozólag biztosította a Sopron város területén kitermelt, és a saját részére szánt erdőtermékek átszállítási jogát Loepersbach osztrák községen keresztül bizonyos, inkább adminisztratív (14 napos bejelentkezési kötelezettség, és jegyzék megléte esetén) feltételek mellett.

A szerződés a kishatárforgalom felszámolásával nem volt gyakorolható. Az 1954. évi felülvizsgálat szerint: „A határörizeti érdekek figyelembevételével nem lenne helyes azt a helyi átmenö forgalmat biztositó jegyzókönyvet érvényben tartani, még akkor sem, ha a mostani gyakorlat bizonyos anyagi megterhelést jelent."

A 2. számú jogi jegyzőkönyv megállapította, hogy a Magyarország és Ausztria közötti határ a 883-as, Írottkỏ magaslaton halad át. A két állam kötelezettséget vállal arra, hogy a lakosságnak minden idöben és minden alakiság nélkül /tehát úti okmány nélkül/ megengedik a magaslaton emelt kilátó megközelítését. Mivel a 883 magaslat fontos háromszögelési pont, a két állam földmérö hivatalai akadálytalanul végezhetnek ott geodéziai munkálatokat.

Az 1954-es viszonyok szerint: „A magaslaton emelt kilátó, mivel a határvonal keresztülhalad rajta, a mü. [müszaki] záron kiviil van. Ilyen formán magyar részról a kilátóba nem járnak fel. Osztrák részról ritkán elöfordul, hogy megközelitik a kilátót. Értesülés szerint a kilátó jelenleg eléggé elhanyagolt állapotban van. Mivel a jegyzökönyvben biztosított jog a kilátó használatára inkább földmérési szempontból lehet jelentös, az illetékesek szakvéleményének alapján továbbra is biztosítani lehetne a 883-as map. [magassági pont] közös használatát. Részünkröl természetesen a határövezet rendjére vonatkozó megszoritások figyelembevételével lehetne csak megközelíteni a kilátót. Határörizeti szempontból minden esetre elönyösebb lenne a kilátó használatának megszüntetése."

Ma a kilátó egy újabban kötött nemzetközi egyezmény eredményeként újra látogatható.

A 3. számú jogi jegyzökönyvben foglaltak szerint az országhatár Inzenhof és Rábafüzes, illetve a C 92/1 és a C 92/2 határkövek között metszi a Szent Imre plébániához tartozó járgányt (keskenyvágányú vasút). A járgány müködése alatt a határátlépés az ott foglalatoskodó emberek és igavonó állatok részére minden alakiság nélkül megengedett. 
A jegyzőkönyvbe foglalt osztrák jogosultság gyakorlati érvényesülésére vonatkozólag meg kell jegyezni, hogy - bár a határ átlépése nem volt kishatárszéli úti okmányhoz kötve - a nyugati határ lezárása alkalmával a helyi átkelő forgalmakat teljes egészében megszüntettük.

Az 1954. évi magyar vélemény szerint: „,Mivel az osztrák jogosultság tárgyát képezö kisvasút már nincs is meg, a jegyzökönyv teljesen idöszerütlen. Érvényben tartása határörizeti szempontból hátrányos és felesleges lenne."

A 4. számú jogi jegyzőkönyv szerint a Hanság csatorna Vallern melletti hídja a vallerni gazdaság részére átkelö helyưl szolgált a magyar területen lévő, mintegy 700 kh. területủ földjeihez. Magyarország biztosítja a község lakóinak a hídon való átkelést. A jegyzőkönyv szerint: ,A hídon való átkelés csak napfelkeltétöl naplementéig van megengedve, azaz március 1-töl november 15-ig 4 és 22 ora között, november 16-tól február végéig 6 és 18 óra között." A határátlépés a kishatárforgalmi úti okmányokkal történik.

A kishatárforgalom felmondásával oka fogyottá vált ez a jegyzőkönyv. „Határörizeti szempontból indokolt megszüntetni azt a jogi kötelességet is." (1954)

Az 5. számú jogi jegyzókönyv Sopron város vízellátására szolgáló vízmúvek védelmére és befejezésére vonatkozott. A Sopron város vízellátására szolgáló müvek védöterületének nagyobb része osztrák területre került. Az Osztrák Kormány kötelezettséget vállalt, hogy ezekre a területekre ugyanúgy alkalmazza az osztrák törvényeket, mint ahogyan azokat osztrák községekre alkalmazná. Ausztria továbbá kötelezi magát arra, hogy segítséget nyújt Sopron városának a védöterületeken foganatosítandó olyan munkálatokkal kapcsolatban, melyekre nézve az osztrák törvények szerint hatósági jóváhagyás szükséges.

A jegyzőkönyv Sopron vízellátására szolgáló mủvek területének határait a következőkben állapította meg:

„Délen és délkeleten Sopron város és Ágfalva község közigazgatási határa, északkeleten a Dudleswald gerince, innen ez a vonal nyugatra a Sopronkertestöl délre fekvő dombok felé kanyarodik, Somfal vától északra átmegy Krippelbergen, majd a lépesfalvai major melletti dombon és a fraknónádasdi Kammhügelt érinti. Azután a Grüssriegel és a fraknónádasdi erdỏ mellett haladva, a vonal keletre a Herrentisch felé kanyarodik, áthalad a Viererriegelen, Loosmaison, Obertödelen, Bremsbergen és az ágfalvi erdő gerincét érinti."

Ha osztrák területen bizonyos építkezésre volna szükség, az osztrák kormány a városnak olyan kedvezményeket nyújt, mint amilyenek hasonló esetekben osztrák községeknek nyújthatók. Az osztrák kormány nem ellenzi, hogy megfelelö feltételek mellett a város a munkákat saját eröivel végeztesse. Az osztrák kormány megkönnyíti a munkák érdekében a határátlépéseket. ${ }^{6}$

Az 1954-es jegyzőkönyv szerint: „A jegyzőkönyv rendelkezései számunkra feltétlenül elönyösek. Elbírálása minden esetre az illetékes szakminisztérium feladata."

Hasonlóképpen született meg a 6. számú jogi jegyzókönyv a Szombathely és Rohonc vízellátására szolgáló mủvek védelmére és befejezésére vonatkozólag. Az 
Osztrák Kormány kötelezettséget vállalt arra, hogy Rechnitz kőzség terủletéről a forrásvíz zárt csöveken Szombathelyre legyen vezethető. A források védőterületére és a vízvezetékek építésére vonatkozólag ugyanúgy kedvezményeket biztosít Ausztria, mint a soproni vízellátással kapcsolatban.

A jegyzőkönyv az osztrák területen fekvő védőterület határait a következőkben jelölte meg:

„A határvonal a Rohonctól északra körülbelül 2 km-re fekvő Satzenriegeltöl keletészakkelet felé kanyarodik, áthalad az 57 -es magassági ponton, követi a hegygerincet észak felé egészen a Kalaposkőig, majd északnyugat felé fordulva a 651-es majd a 691-es magassági pontokon át a gerincen haladó utat követi az Irottkő gerincéig.

Innen a gerinc nyugat felé halad a 823-as, majd a 832-es magassági ponton át, egészen addig a gerincútig, amely a 830 és 858 magassági pontok között délfelé fordul, azután ezt a gerincutat követi a 651 -es magassági ponton át a Budiriegelig. Ettól a ponttól kezdve a vonal egyenes irányba halad a Satzenriegelig."

Az 1954-es jegyzökönyv hasonló megállapításokat tartalmaz, mint az elöző jegyzőkönyv esetén: „A jegyzőkönyv rendelkezései számunkra feltétlenül előnyösek. Elbírálása minden esetre az illetékes szakminisztérium feladata."

A 7. sz. jogi jegyzökönyv Köszeg város vízellátásának szabályozásáról szól. Az osztrák kormány megengedi a Hétforrás vizének osztrák területen - Rattersdorf községen - keresztuil Köszeg város területére való vezetését. Ezzel kapcsolatban az osztrák kormány ugyanolyan kedvezményeket biztosít, mint a soproni vízellátás esetében.

Az 5, 6, 7. jegyzőkönyvek tartalmuk és elönyük miatt hasonlóak, ezért az 1954-es jegyzökönyv közös megállapításokat is szükségesnek tartott: „Amennyiben az értekezleten az 5., 6. és 7. jkv. érvényben tartását indokoltnak minösítik, úgy részünkröl javaslom olyan álláspontra helyezkedni, hogy az ebböl kifolyólag szükséges határátlépések kizárólag csak érvényes útlevél alapján történhessenek. Bár részünkröl elönyösebb lenne megszüntetni mind a három jegyzőkönyv hatályát, ezt a kérdést azonban magasabb érdekek figyelembe vételével kell elbirálni, amik elóreláthatólag az értekezleten fognak felszínre kerülni."

A 8. számú jogi jegyzőkönyv a határvonal jelzésére szolgáló határkövek, oszlopok és jelzések védelmére és fenntartására vonatkozott.

Mindkét állam kötelezi magát, hogy a határjeleket megvédik. Gondoskodnak arról, hogy a határt alkotó vizek partjai, valamint az utak megmaradjanak eredeti állapotukban. Megállapodást tartalmaz a jegyzőkönyv a határjelek helyreállítása, pótlása és javítása, valamint a kártérítési kérdésekben is.

A Magyar Köztársaságnak (és az elód álamnak) minden szomszédjával volt és van határrendi szerződése, amely a határ kijelölésre, határjelek sérthetetlenségére, karbantartására vonatkozik. Talán ezért is furcsa az idézett jegyzőkönyv 1954. évi megítélése, amely a következő volt: ,A jegyzőkönyv rendelkezései a felszabadulás óta nem érvényesülnek. A határ megjelölése osztrák viszonylatban eléggé elhanyagolt állapotban van. Kétségtelenül fontos, hogy a két állam között legyen ilyen tárgyú megállapodás a jövöben is. Figyelembe kell venni, hogy szuikségessé fog 
válni osztrák viszonylatban is a határvonal karba helyezése és igy egy részletes szabályozásra lesz majd szükség a munkálatok végrehajtására vonatkozóan. A 8. sz. jegyzökönyv rendelkezései csak nagy vonalakban ugyan, de méltányos elvek alapján szabályozzák a kérdést. Éppen ezért a magunk részéröl javasolni kellene ezeknek a jkv.-nek a felmondását, de csak azzal a feltétellel, hogy egy új és részletes egyezményt kössünk ebben a tárgyban az osztrákokkal."

A 9. sz. jogi jegyzókönyv az Eszterházy-uradalom erdőtermékeinek osztrák területen való átszállítását szabályozza. A volt Eszterházy-uradalom magyarországi erdőterményeinek Rattersdorf és Liebing osztrák községek területén megfelelö feltételek mellett való átszállításának lehetőségét biztosítja magyar területre.

Az 1954-es megítélés szerint ,A jegyzőkönyvben Magyarország szárma biztosított jog az akkori útviszonyok miatt volt jelentős. Még 1948-ban is komoly nehézségekben ütközött az erdötermékek magyar területen való elszállítása. Lehetséges, hogy azóta már épitettek új utakat, melyek feleslegessé teszik a jegyzökönyvben foglalt jogosultság gyakorlását. Ennek elbírálása az illetékes szakhatóságok feladata. Magyar részröl semmiféle átmenö forgalom nincs ott 1949 óta.

Részünkröl a felmondás mellett kellene állást foglalni, ugyanis ha a fa kitermelés és szállítás 1949 óta magyar területen át megoldható volt, úgy az megoldható lesz a jövöben is. - Viszont határörizeti szempontból nem helyes nyugaton a helyi határforgalmat engedélyezni."

A 10. számú jogi jegyzőkönyv rendelkezéseket tartalmaz az általános vízügyi megállapodás szellemében a lutzmannsburgi zsilip kezelésére és karbantartására nézve. Az 1954-es felülvizsgálat szerint ,A rendelkezésre alló adatok szerint a szóban forgó zsilip magyar vonatkozásban komoly jelentöséggel bír. Elbírálása azonban az illetékes szakminisztérium feladata."

A 11. számú jogi jegyzőkönyv azokról a közös mủutakról és utakról rendelkezik, melyeknek hossztengelye az államhatárral egybeesik. Ezeket az utakat ugyanazon állam két pontja közötti közlekedésre, ennek az államnak a polgári útlevél és egyéb úti okmány nélkül teljes szélességükben szabadon használhatták. Ezeken az utakon ugyanazon állam két pontja között szállított áruk az illető állam területén lévőknek voltak tekintendök. A közös utakon szolgálatban álló rendészeti és vámközegek (csendörség, közbiztonság és vámőrség szolgálatában állók) teljes felszereléssel járhattak. Szolgálaton kívül tilos volt a fegyver viselése a közös utakon. A németújvári és a nagykölkedi út kivételével a hadsereg nem vehette igénybe a közös utakat.

A rendelkezés szerint 22 közös út volt. A vasfüggöny után ezek közös használata lehetetlenné vált, a határövezet, határsáv adminisztratív akadályai miatt szinte csak az osztrák fél élvezte elönyét, pl. Rábafüzesnél.

A 12. számú jogi jegyzőkönyv szerint a határ közelében lévö, illetve a határon áthaladó műutakat és hidakat a két állam érdekelt szervei tartották karban. Az illetékes hivatalok alkalmazottainak biztosította a két ország a határzónában való közlekedés megkönnyítését. Ugyanígy biztosította a két ország az utak és hidak karban- 
tartásához szükséges anyagok határ menti beszerzésével, illetve szállításával kapcsolatban a legnagyobb kedvezményeket.

Az 1954-es magyar felülvizsgálat szerint: ,A jegyzökönyvben foglaltak a gyakorlatban nincsenek alkalmazva jelenleg és amennyiben a 11. sz. jegyzökönyv megszünik, ennek a jegyzökönyvnek az érvényben tartása is felesleges."

A 13. számú jogi jegyzökönyv arról rendelkezett, hogy a Hanság csatorna és gátja mentén (annak északi oldalán) húzódó, mintegy 2,5 km hosszúságú utat, valamint a védgát tetejét az A 62 és A 71 föhatárkövek között az osztrák csendörség és vámörség tagjai hivatásuk teljesítése közben gyalogosan bármikor használhassák. Ugyanígy joguk volt a szóban forgó $2,5 \mathrm{~km}$-es útszakasz használatára Pamhagen osztrák község lakosainak is, akár gyalogosan akár kocsival. Polgári személyek részére a jegyzőkönyv elöírta azt, hogy úti okmánnyal rendelkezniük kell. Meg kell jegyezni, hogy a szóban forgó út és a csatorna gátja teljes egészében magyar területen fekszik.

$\mathrm{Az}$ 1954-es jegyzökönyv részletesen foglalkozik a pamhageni mütárgyak sorsával, amely szerint: „A jegyzökönyvbe foglalt osztrák jogositványokkal kapcsolatban a megváltozott viszonyok és a volt kishatárszéli forgalmi egyezmény felmondása a gyakorlat teljes mértékü megváltozását eredményezte.

Az osztrákok úthasználatának lehetösége részben már nincs is meg. A müzár egy része ugyanis a csatorna É-i védgátján van megépitve. A jobbszárnyon elöfordul azonban, hogy az osztrák fináncok bejárnak a magyar területen lévö útra.

Határörizeti szempontból teljesen felesleges és helytelen érvényben tartani a jegyzökönyvet és a hatályon kívül helyezés mellett kell állást foglalni."

A 14. számú jogi jegyzökönyv Rattersdorf osztrák községnek és plébániájának a volt Eszterházy erdőbirtok területéről fával és alommal való ellátási jogát biztosította. Magyarország kötelezte magát, arra, hogy az osztrák jogból kifolyólag megengedi a szóban forgó áruk kivitelét mindennemủ korlátozás nélkül.

Igen részletesen foglakozik ezzel a jogi jegyzökönyvvel a témát 1954-ben felülvizsgáló szakember. Megállapításai szerint: „Az ebben a jegyzőkönyvben foglalt jogosítványra az osztrákok igen nagy súlyt fektetnek. Ezt a kérdést minden alkalommal felvetik a tárgyalások során. Ez a jogositvány számukra feltétlenül elönyös, Magyarországra pedig inkább terhet jelent. Az osztrákok jogának gyakorlása jelenleg részünkröl nincs engedélyezve.

A II. világháború befejezéséig, bár a volt Eszterházy Hitbizomány kérte a magyar részrôl vállalt kötelezettség megszüntetését az akkori Magyar Kormánytól, a jegyzökönyvben lerögzített jog a gyakorlatban érvényesült.

A gyakorlat szerint az Eszterházy erdöbirtok évenként $66 \mathrm{~m}^{3}$ fát adott át az osztrák községnek térítés nélkül. A rözse és alomgyüjtésre a rattersdorfi elöljáróság jelölte ki a község szegényebb lakói közül az igényjogosultakat, akik meghatározott helyen és idöben kishatárszéli úti okmánnyal lépték át a határt. Az erdögazdaság évenként más más területet jelölt ki a rözse és alomgyüjtés céljára. 
A FM. kiküldöttei által 1949-ben lefolytatott helyszíni vizsgálat jegyzőkönyve az alábbiakat állapítja meg.

„A jogi jegyzőkönyvben foglalt szolgáltatások az állami erdőgazdálkodásra súlyos terheket jelentenek és az Egyezmény többi jogi jegyzőkönyveiben biztosított előnyökhöz képest jelentéktelennek kell minősíteni, annak dacára, hogy különösen az alomszedés kérdése erdőgazdasági szempontból még a gyakorolt mértékben sem mondható kívánatosnak. Határőrizeti szempontból - mivel a jegyzỏkönyv érvényben tartása helyi határforgalom engedélyezését jelentené - javasoljuk a hatályon kívül helyezés mellett dönteni."

A 15. számú jogi jegyzókönyv Halbturn község lakói számára az Oberes Fuchsenfeld területén végzendỏ mezei munkák végrehajtása érdekében a 39. és 42 . sz. főhatárkövek között magyar területen futó utat megfelelő határigazolvány birtokában szabadon használhatóvá tette. A kishatárforgalmi szerződések elhalásával ez a jegyzőkönyv is hatályát vesztette.

A 16. számú jogi jegyzőkönyvben az Osztrák Kormány kötelezettséget vállalt arra nézve, hogy a Kislajta vizét a Mária-liget melletti magyar területek öntözése céljából a Rétárokba (Wiesgraben) vezetik. Kezeskedett Ausztria, hogy a Rétárkot nem fogják a Kislajta árvizeinek levezetésére felhasználni.

A magyar fél 1954. évi szakértỏi véleménye szerint: „A jegyzőkönyv rendelkezései magyar szempontból előnyösek. Az osztrák hatóságok az elmúlt időkben azonban nem tartják be az öntözővíz szolgáltatással kapcsolatos kötelezettségeiket. A kérdés elbírálása az illetékes szakminisztériumra tartozik. A határörizetre nézve az árvízveszély szempontjából van jelentősége."

Az osztrák-magyar határ Zeiselhofnál kettévágta a volt Lőnyai féle hercegi birtokot. A 17. számú jogi jegyzőkönyv biztosította, hogy a gazdálkodási egység fenntartása érdekében a birtok alkalmazottai a gazdaság területén bárhol átléphessék kishatárszéli úti igazolvány birtokában - a határt, és azon keresztül szállíthassák a termelvényeket, adó és vámmentesesen.

1954-ben az alábbi vélemény alakult ki: „A II. világháború után teljesen megváltozott tulajdoni viszonyok, valamint a kishatárszéli forgalom beszüntetése a jegyzőkönyv rendelkezéseit teljesen időszerütlenné teszik. Szempontunkból a felmondás mellett kellene állást foglalni."

A 18. számú jogi jegyzökönyv értelmében Kőszeg város részére az osztrák hatóságok megengedték, hogy a Zeigerbergtől nyugatra lévő magyar erdőrész termékeit Idebig községen (osztrák területen) át Magyarországra szállíthassák, megfelelö feltételek betartása mellett.

„Ennek a megállapodásnak az ottani hiányos útviszonyok miatt volt jelentösége. Magyarország nem él az átszállítás jogával és határörizeti szempontból sem helyes ilyen lehetöséget biztositani, és ennek alapján javasoljuk a jegyzökönyv hatályon kivül helyezését." - írták a jegyzőkönyvről 1954-ben.

A 19. számú jogi jegyzökönyvben az Osztrák Kormány kötelezi magát, hogy adómentesen engedélyezi annyi ásványvíznek Deutschkreutzból Harkára való szállítá- 
sát, amennyihez Harka lakosainak a források tulajdonosaival meglévő szerzödések alapján joguk van.

1954-ben már ez a jegyzőkönyv sem állta meg a helyét: „Tudomásunk szerint a jegyzökönyv rendelkezései a változott viszonyok miatt a gyakorlatban nem érvényesülnek és a jegyzökönyv érvényben tartás is teljesen felesleges, mivel az osztrák forrás tulajdonosaival történö megállapodás a víz eladás tekintetében semmivel sem indokolható".

A közös államhatáron való áthaladást biztosító határátkelőhelyek kijelölésére ,A m. kir. belügyministernek 5,645/1923. B. M. számú körrendelete" intézkedett, amely szerint a határátkelöhelyek a következők:

Szentgotthárd, Kőszeg, Sopron, Hegyeshalom.

A fenti rendeletet az alábbiakkal egészítette ki az 1931. évi jan. 23-án kiadott 124.055-931-VII. sz. rendelet:

\section{Zsira-Locsmánd}

Nemes-Locsmánd

Bucsu-Rohoncz

Alsócsatár-Csajta

Pornóapáti-Felsőbeled

Szentpéterfa-Felsőbeled

Szentpéterfa-Nagysároslak

Pinkamindszent-Nagysároslak

\section{Összefoglalás}

A jogi jegyzökönyvekkel már korábban is foglakozott egy tárcaközi bizottság, de nem jutott eredményre. Az 1954-es felülvizsgálat jól mutatja a korszak sajátosságait, amikor az államhatár elválasztó szerepe dominált az osztrák-magyar határkapcsolatokban. Különösen visszavetette a határkapcsolatokat az a tény, hogy a határszéli kishatárforgalom, amely más baráti állammal késöbb új formában visszaállításra került, az osztrák viszonylatban elhalt.

A helyzet normalizálódását segítette elö az 1964-ben aláirt határszerzỏdés, amikor is mindkét országban felismerték, hogy a jó viszony kiépitésének és fenntartásának elengedhetetlen feltétele az államhatár határjeleinek újra kitüzése, azok láthatóságának biztosítása. Ez egy hosszú út kezdete volt, amely elvezetett az Elektromos Jelzörendszer felszámolásához, új határátkelöhelyek nyitásához, és a mai napokban funkcionáló osztrák-magyar határórizeti szervek közös kapcsolattartó (Hegyeshalom-Nickelsdorf) pontjának létrehozásához. 


\section{Jegyzetek}

${ }^{1}$ A M. Kir. Minisztérium 1926. évi 11.110. M. E. számú rendelete, a kisebb határszéli személyforgalom szabályozása tárgyában az Osztrák Köztársasággal kötött megállapodás életbeléptetéséről.

${ }^{2}$ A m. kir. minisztérium 1970/1928. M. E. rendelet a magyar-osztrák határmegállapítás kapcsán felmerủlt jogi kérdések rendezése céljából szerkesztett jogi jegyzőkönyveket magában foglaló, az Osztrák Köztársasággal Bécsben, 1927. március 11. napján kötött egyezmény kihirdetéséröl.

${ }^{3}$ Feljegyzés. Budapest, 1954. január 4-én. Belügyminisztérium. Határörség és Belső Karhatalom Parancsnoksága.

${ }^{4}$ Jogi jegyzőkönyv, a Magyarország és Ausztria közötti határvidék vízủgyeinek, az osztrák-magyar Határmegállapító Bizottság által a Dunai Állandó Vízủgyi Mủszaki Bizottsággal egyetértésben, a Nemzetek Szövetsége Tanácsának a Bizottsághoz a Nagykövetek Tanácsa 1922. október 21-i jegyzékével megküldött, 1922. szeptember 19-i határozata szerint megállapított szabályozására vonatkozólag.

${ }^{5}$ A kishatárforgalomról szóló egyezményt lásd feljebb.

${ }^{6}$ Az 1954-es jegyzőkönyv szerint: „A jegyzökönyv rendelkezései számunkra feltétlenül elönyösek. Elbirálása minden esetre az illetékes szakminisztérium feladata."

\section{Irodalom}

Sallai J. (1996) A magyar-osztrák határ történetéroỏl a XVIII. századtól napjainkig. - Soproni Szemle. 4. 289-301. o.

Sallai J. (2002) Magyarország államhatárainak és a magyar etnikai határok történetének kapcsolata. PhD disszertáció. DTE BTK, Debrecen.

Suba J. (1999) Magyarország határának kitũzése és felmérése 1921-1925 között. MH Tájékoztatási és médiaközpont, Budapest. 